\title{
ANALISIS EFEKTIFITAS PENDEKATAN HUMAN CENTER DESIGN DALAM PENGEMBANGAN INDUSTRI KECIL MENENGAH DI KAWASAN PEDESAAN
}

\author{
Devi Maulida Rahmah ${ }^{1)}$ \\ ${ }^{1)}$ Staf Pengajar Fakultas Teknologi Industri Pertanian Universitas Padjadjaran \\ Alamat : Jl. Raya Bandung - Sumedang KM 21 Jatinangor \\ Email : d.m.rahmah@gmail.com
}

\begin{abstract}
ABSTRAK
Pendekatan human center design merupakan sebuah pendekatan dengan menitikberatkan manusia sebagai pusat dalam setiap aktifitas di dalam sistem. Industri manufaktur telah lebih dulu menerapkan pendekatan ini dalam meningkatkan produktifitas, efisiensi, dan efektifitas proses kerja sistem industri. Pendekatan ini jika dianalisis lebih dalam dapat diterapkan pada sistem yang jauh lebih kecil dan sederhana. IKM merupakan sistem industri yang lebih sederhana. Penelitian ini bertujuan untuk mengetahui efektitas penerapan pendekatan human center design dalam Industri Kecil menengah ditinjau dari produktifitas usaha yang dijalankan. Penelitian dilakukan di Paguyuban IKM yang ada di Desa Pagedangan Kec.Indramayu. Metode yang dilakukan adalah dengan wawancara terstruktur pada pelaku IKM seteah pendekatan Human center design ini diterapkan sebelumnya. Hasil Penelitian menunjukkan bahwa terdapat peningkatan efektifitas aktifitas usaha yang dilakukan terhadap peingkatan motivasi pelaku IKM untuk mengembangkan IKM yang dikelolanya sejumlah $75 \%$, peningkatan omset penjualan sebesar $25 \%$, penguatan jejaring pasar, serta kemampuan melakukan inovasi produk.
\end{abstract}

Kata kunci : human center design, IKM pedesaan

\begin{abstract}
Approach to human center design is an approach with an emphasis on human beings at the center of every activity in the system. The manufacturing industry had already applying this approach to increase productivity, efficiency, and effectiveness of work processes industrial systems. This approach when analyzed more deeply can be applied to a system that is much smaller and simpler. IKM is an industrial system much simpler. This study aims to determine efektitas human approach application design center in the Small Industries medium in terms of the productivity of the business carried on. The study was conducted at the Association of SMEs in the Pagedangan village, district of Indramayu. The method is a structured interview conducted at HPI actors seteah Human center design approach is applied beforehand. Research results show that there is an increase in the effectiveness of the business activity conducted on offender motivation deficits improve SME to develop SMEs which manages some $75 \%$, increase sales turnover by $25 \%$, strengthening the networking market, as well as the ability to innovate products.
\end{abstract}

Keywords: human center design, rural smallholder

\section{PENDAHULUAN}

Pengembangan industri kecil menengah di kawasan pedesaan tidak hanya dinilai sebagai salah satu cara efektif dalam mengatasi permasalahan pengangguran, namun juga mampu menciptakan mental masyarakat mandiri secara ekonomi. Masyarakat yang mandiri menjadi modal besar untuk meningkatkan IPM di suatu daerah.

Desa Pagedangan Kecamatan Tukdana Kabupaten Indramayu merupakan desa yang memiliki permasalahan tingkat pengangguran yang cukup tinggi. Jika ditinjau lebih mendalam, potensi untuk dikembangkannya industri rumah tangga di desa tersebut masih ada yaitu melalui pengembangan industri yang sudah ada di desa tersebut dengan meningkatkan produktifitas .

Pengembangan industri kecil menengah di kawasan pedesaan memiliki tantangan tersendiri. Pendekatan yang dilakukan harus mampu mempertimbangkan faktor pendidikan, ekonomi, karakter penerimaan terhadap hal baru (transfer teknologi), serta faktor lainnya 
yang berkaitan dengan latar belakang pelaku IKM. Pendekatan yang dilakukan diharapkan mampu melahirkan kesadaran secara pribadi dari pelaku IKM untuk mengembangkan usaha yang dimilikinya.

Human centered Design merupakan sebuah pendekatan yang menitikberatkan pada aspek manusia sebagai pusat dalam melakukan perancangan atau perbaikan sistem. Kegiatan pengembangan erat kaitannya dengan aktifitas perbaikan di dalam IKM. Perbaikan yang dilakukan Perbaikan sistem IKM dapat meliputi kegiatan transfer teknologi berupa teknologi atau cara baru dalam berproduksi, inovasi proses produksi, inovasi produk, teknologi pengemasan, perluasan pasar, penguatan jejaring, hingga perbaikan sarana dan prasarana tempat produksi.

Pendekatan human centered design menempatkan pertimbangan aspek manusia dalam setiap perancangannya. Sebagai contoh aktifitas penerapan mesin atau alat pengolah yang diharapkan mampu meningkatkan produktifitas usaha harus memperhatikan aspek latar belakang pendidikan pemakai, kemampuan menerima hal baru, serta aspek social masyarakat setempat. Teknologi yang diterapkan harus mampu memberikan dampak baik pada pelaku IKM, komponen pendukung dalam IKM, serta masyarakat sekitar.

Dalam inovasi produk pendekatan human centered design berperan dalam menganalisis yang berkaitan dengan aspek kesiapan produsen serta aspek konsumen (kecenderungan latar belakang pendidikan segmentasi yang dibidik, kondisi sosial ekonomi, dan lainnya). Dengan pendekatan ini diharapkan pengembangan IKM di pedesaan dapat terealisasi.

Tujuan penelitian ini adalah mengukur efektifitas penerapan human center design dalam meningkatkan produktifitas dan performansi IKM. Melakukan pengukuran produktifitas usaha berupa jumlah produksi, kemampuan melakukan inovasi produk, omset usaha, perluasan pasar. Mengidentifikasi proses-proses perbaikan yang dilakukan. Menganalisis kemungkinan model-model pendekatan dalam pengembangan IKM.

\section{METODE PENELITIAN}

Penelitian dilakukan dengan melakukan analisis terhadap aktifitas produksi yang dilakukan dalam kurun waktu 5 (lima) bulan pasca diterapkannya metode human centered design (HCD). Penelitian yang didesain secara kualitatif ini dilakukan melalui teknik diskusi kelompok terfokus (focus group discution) wawancara mendalam dan observasi langsung (observasi partisipatif). Penelitian dilakukan di Kelompok IKM desa Pagedangan Kabupaten Indramayu.

Adapun tahapan penelitian ini adalah: Pertama, focus group discution (FGD), yang meliputi: (1) analisis kondisi eksisting IKM yang ada di desa; (2) mengajak pelaku IKM untuk menganalisis sebab akibat kondisi saat ini; dan (3) menemukan solusi bersama dengan titik tekan aspek manusia yang menjadi pertimbangan dalam setiap perbaikan yang dilakukan; Kedua, melakukan pendampingan sesuai targetan bersama dalam menerapkan teknologi, cara baru, inovasi produk, serta pemasaran; dan Ketiga, menganalisis kondisi pasca proses-proses perbaikan dilakukan.

Berikut adalah proses penelitian yang dilakukan: Tahap 1 (Pra Penelitian). Pada tahapan ini pendekatan lebih dititikberatkan pada tokoh masyarakat, aparat desa terkait, dan objek yang dituju dalam proses pengembangan IRT dan pemberdayaan masyarakat di wilayah Pedesaan menjadi hal terpenting yang pertama kali harus dilakukan. Karakteristik masyarakat desa yang masih kental dengan penokohan (local leader), kekeluargaan, dan agamis, yang mendorong proses pendekatan diatas.

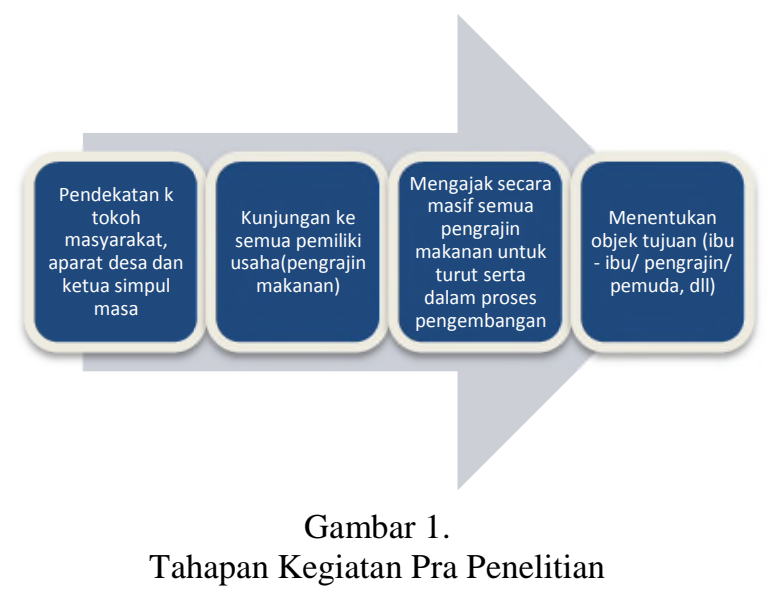

Pengembangan IKM merupakan sebuah proses yang bertahap. Beberapa tahapan yang harus dilakukan adalah mengetahui masalah, kendala, potensi, hingga solusi yang akan dilakukan. Solusi yang dilakukan dapat berupa pengembangan Industri rumah tangga berbasis olahan pangan tradisional, pengembangan produk yang sudah ada lalu diversifikasi, strategi penyedian bahan baku yang berkelanjutan, rencana pemberdayaan pekerja, 
objek pekerja, strategi pemasaran, dan lainya. Dari solusi yang dihasilkan, ada proses tindak lanjut sesuai rekomendasi solusi tersebut.

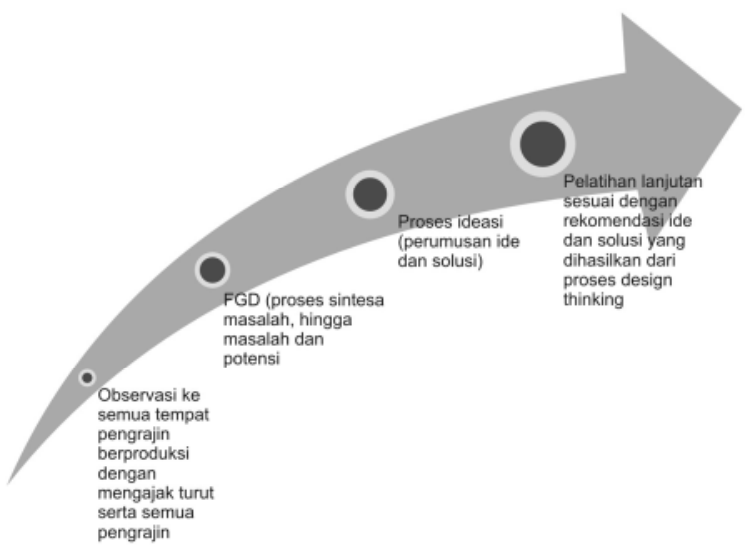

Gambar 2. Proses analisis kondisi eksisting IKM

Tahap 2 (Pasca Penerapan Solusi dengan HCD). Serangkaian kegiatan penerapan human centered design dalam pengembangan IKM harus disertai dengan proses monitoring dan pendampingan yang berkelanjutan. Dalam sebuah proses bisnis hal terpenting lainnya setelah melakukan inovasi adalah menjaga konsistensi dan komitmen untuk terus memasarkan produk, inovasi produk secara berkelanjutan, dan strategi pencapaian visi yang lebih besar. Berikut adalah alternative kegiatan yang bisa dilakukan (Gambar 3).

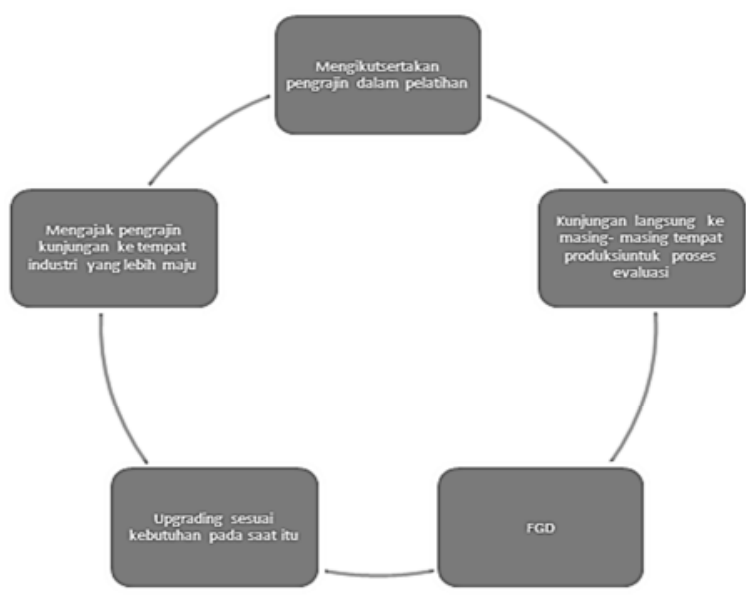

Gambar 3. Proses monitoring dan pendampingan

Proses monitoring dan pendampingan merupakan proses penting untuk menjaga komitmen dan konsistensi proses produksi dan inovasi di tingkat pengrajin. Karena dalam suatu proses bisnis, ada saat dimana pemasaran terhambat, masalah muncul baik dari sisi produksi, konflik internal kelompok pengrajin, atau masalah yang bersumber dari eksternal; yang menyebabkan semangat yang menurun di tingkat pengrajin. Permasalah di atas harus segera ditangani untuk menghindari permasalahan yang jauh lebih besar. Pola komunikasi yang baik (interaktif, dialogis dan partisipatif) dengan pengrajin akan memudahkan penyelesaian permasalahan-permasalahan yang terjadi dalam kelompok pengrajin.

Data yang dibutuhkan dikumpulkan dari tingkat produksi, varian inovasi dan perluasan pasar. Data diperoleh dari pengrajin IKM yang melakukan proses pengamatan pada tiap pekannya serta proses wawancara terstruktur pasca penerapan human center design dalam proses bisnis IKM. Data yang diolah berupa data sekunder yang diperoleh dari pelaku IKM Desa Pagedangan berupa Data produksi, varian produk hasil inovasi, omset penjualan, serta perluasan pasar.

Data diolah menggunakan Uji statistik sederhana dengan menggunakan Uji T untuk mengetahui sifat perbedaan komponen produktifitas IKM pasca diterapkan perbaikan dengan konsep HCD. Uji t sample berpasangan sering kali disebut sebagai paired-sampel t test. Uji t untuk data sampel berpasangan membandingkan rata-rata dua variabel untuk suatu grup sampel tunggal. Uji ini menghitung selisih antara nilai dua variabel untuk tiap kasus dan menguji apakah selisih rata-rata tersebut bernilai nol.

Kriteria data untuk uji t sampel berpasangan: skala interval atau rasio, data berdistribusi normal dan nilai variannya dapat sama ataupun tidak. Uji t berpasangan (paired t-test) umumnya menguji perbedaan antara dua pengamatan. Uji seperti ini dilakukan pada Subjek yang diuji untuk situasi sebelum dan sesudah proses, atau subjek yang berpasangan ataupun serupa (sejenis).

\section{HASIL DAN PEMBAHASAN}

\section{Karakteristik IKM Pedesaan}

Berdasarkan hasil observasi lapangan dalam rangkaian proses FGD diperoleh hasil sebagai berikut: (1) terdapatnya kekhasan IKM di Pedesaan dengan IKM di daerah Perkotaan, sehingga kekhasan inilah yang menjadi pertimbangan utama dalam melakukan aksi perbaikan; dan (2) IKM pada umumnya bergerak pada sector agro serta produk turunannya (Tabel 1). Berdasarkan hasil analisis kondisi IKM di pedesaan diperoleh diagram sebab akibat (Gambar 4). 
Tabel 1. Kondisi kekinian di Lapangan (IRT berbasis olahan pangan di Pedesaan)

\begin{tabular}{|c|c|c|c|c|c|}
\hline \multicolumn{6}{|c|}{ Kondisi Eksisting Hasil Sintesa di Lapangan } \\
\hline \multicolumn{6}{|c|}{ Faktor } \\
\hline SDM & Modal & Manajemen & Pemasaran & Bahan Baku & Produk \\
\hline $\begin{array}{l}\text { Jumlah pekerja } \\
\text { yang terserap masih } \\
\text { sangat minim, } \\
\text { bergantung pada } \\
\text { banyaknya pesanan }\end{array}$ & $\begin{array}{l}\text { Modal sangat } \\
\text { minim }\end{array}$ & $\begin{array}{l}\text { Pengetahuan yang } \\
\text { rendah dari pemilik } \\
\text { usaha tentang semua } \\
\text { hal terkait manajerial }\end{array}$ & $\begin{array}{l}\text { Pemasaran masih } \\
\text { minim }\end{array}$ & $\begin{array}{l}\text { Masih } \\
\text { bergantuntg } \\
\text { pada penyedia } \\
\text { bahan baku, } \\
\text { belum mampu } \\
\text { menyediakan } \\
\text { secara mandiri } \\
\end{array}$ & $\begin{array}{l}\text { Belum memiliki } \\
\text { pengetahuan } \\
\text { mengenai } \\
\text { pengembangan } \\
\text { produk (dari } \\
\text { segi varian dan } \\
\text { kemasan) } \\
\end{array}$ \\
\hline $\begin{array}{l}\text { Skill yang sangat } \\
\text { rendah mengenai } \\
\text { pengolahan pangan } \\
\text { yang baik dan } \\
\text { inovatif }\end{array}$ & $\begin{array}{l}\text { Bergantung pada } \\
\text { jumlah pesanan }\end{array}$ & $\begin{array}{l}\text { Belum menerapkan } \\
\text { prinsip ekonomi } \\
\text { dalam produksi } \\
\text { produk. Masih } \\
\text { sebatas "yang penting } \\
\text { ada untung" }\end{array}$ & $\begin{array}{l}\text { Belum menerapkan } \\
\text { strategi sosialisasi } \\
\text { produk secara } \\
\text { masif (misal } \\
\text { memasang stand di } \\
\text { acara-acara } \\
\text { insidental di } \\
\text { desa/kecamatan, } \\
\text { liflet, banner dll) }\end{array}$ & & \\
\hline $\begin{array}{l}\text { Pengetahuan yang } \\
\text { rendah mengenai } \\
\text { proses produksi } \\
\text { berorientasi } \\
\text { kualitas }\end{array}$ & $\begin{array}{l}\text { Masih jarang yang } \\
\text { memanfaatkan } \\
\text { koperasi simpan } \\
\text { pinjam/pinjaman } \\
\text { dari bank }\end{array}$ & $\begin{array}{l}\text { Tidak ada aturan } \\
\text { yang mengikat untuk } \\
\text { pekerja }\end{array}$ & $\begin{array}{l}\text { Belum } \\
\text { memberdayakan } \\
\text { komunitas desa } \\
\text { (pemuda, PKK, ibu } \\
\text { pengajian) dalam } \\
\text { membantu } \\
\text { pemasaran }\end{array}$ & & \\
\hline $\begin{array}{l}\text { Pekerjaan } \\
\text { menggunakan } \\
\text { sistem borongan }\end{array}$ & & $\begin{array}{l}\text { Belum memiliki visi } \\
\text { misi yang jelas atau } \\
\text { target usaha jangka } \\
\text { panjang }\end{array}$ & & & \\
\hline
\end{tabular}

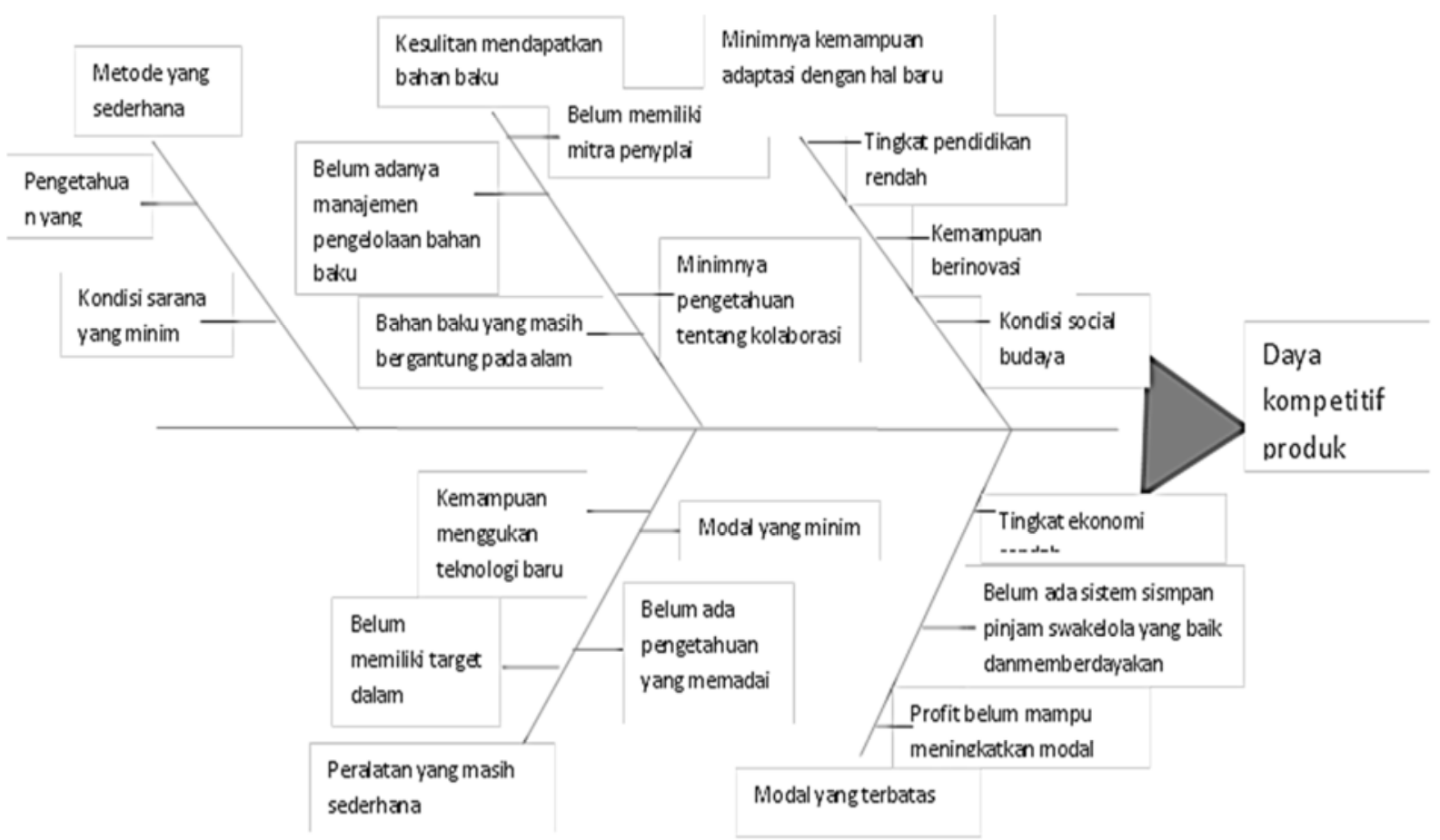

Gambar 4. Diagram Fish Bon Sebab Akibat IKM 


\section{Hasil Pengukuran Jumlah Produksi}

Berdasarkan data yang diperoleh dari pelaku IKM, jumlah produksi keripik pada IKM sebelum dan setelah melakukan aktifitas perbaikan berdasarkan pendekatan human centered design adalah sebagai berikut :

Tabel 2. Rata-rata produksi per pekan $(\mathrm{kg})$

\begin{tabular}{lcc}
\hline & Sebelum & Sesudah \\
\hline $\begin{array}{l}\text { Rata - Rata Produksi } \\
\text { / minggu }\end{array}$ & 18.83333 & 31.5 \\
\hline
\end{tabular}

Sekilas dengan melihat rata-rata jumlah produksi per minggunya, terlihat adanya kenaikan jumlah produksi setelah IKM melakukan perbaikan dengan pendekatan human centered design. Lembih lanjut Uji T dilakukan untuk mengetahui signifikansi perbedaan akibat pendekatan human centered design. Berikut adalah hasil yang diperoleh :

Tabel 3. Hasil uji T

\begin{tabular}{lccccc}
\hline \multicolumn{5}{c}{ Independent Samples Test } \\
\hline \multicolumn{1}{c}{$\begin{array}{c}\text { Levene's Test } \\
\text { for Equality of } \\
\text { Variances }\end{array}$} & & & & \\
\hline & $\mathrm{F}$ & Sig & $\mathrm{T}$ & Df & $\begin{array}{l}\text { Sig.(2- } \\
\text { tailed) }\end{array}$ \\
\hline $\begin{array}{l}\text { Jumlah produksi } \\
\begin{array}{l}\text { Equal variances } \\
\text { assumed }\end{array}\end{array}$ & 1.942 & .169 & -6.953 & 58 & .000 \\
$\begin{array}{l}\text { Equal variances } \\
\text { not assumed }\end{array}$ & & & -6.953 & 54.890 & .000 \\
\hline
\end{tabular}

Hasil pengujian menunjukan $\mathrm{T}$ table sebesar 0.00 dimana nilai $\mathrm{T}$ table $<\mathrm{T}$ hitung, yaitu $0.00<0.05$ hal ini berarti terdapat perbedaan yang signifikan jumlah produksi IKM sebelum melakukan perbaikan sistem kerja dengan setelah menerapkan perbaikan sistem dengan pendekatan human centered design.

Menurut Rahmah (2014) bahwa output dari aktifitas produksi dapat dikategorikan kedalam 2 hal, yaitu output kualitas dan Kuantitas. Kualitas dapat berupa inovasi produk, kemudahan produk diterima di masyarakat, produk yang menarik, dll. Sedangkan output Kuantitas adalah jumlah produksi. Output aktifitas produksi ini dapat menjadi ukuran bagi produktifitas aktifitas IKM. Hasil penelitian mengenai jumlah produksi yang menunjukkan adanya peningkatan yang signifikan dapat berarti bahwa penerapan perbaikan dengan pendekatan human centered design mampu meningkatkan produktifitas IKM.

\section{Proses Inovasi}

Berdasarkan hasil wawancara terstruktur dengan pemilik IKM, inovasi produk dengan pendekatan human centered design dilakukan dengan mempertimbangkan hal-hal sebagai berikut : (1) Kemampuan pelaku IKM dalam melaksanakannya (mampu produksi). Hal ini berkaitan dengan keterampilan sumber daya manusia IKM dalam melakukan dan merealisasikan inovasi yang direncanakan; (2) Kesiapan sarana prasara yang mendukung terealisasinya proses inovasi; (3) Karakteristik calon konsumen yang menjadi segmentasi pasar; (4) Kondisi social budaya masyarakat sekitar; dan (5) memulai dengan hal-hal sederhana namun berdampak terhadap grafik produktifitas dan penerimaan pasar terhadap produk yang dihasilkan. Hasil pengolahan data melalui coding dari Proses inovasi yang dilakukan berdasarkan urutan adalah:

Tabel 4. Proses Inovasi Hasil Coding

\begin{tabular}{|c|c|c|}
\hline Kategori & Sub Kategori & Proses inovasi \\
\hline Man & $\begin{array}{ll}\text { - } & \text { Motivasi } \\
\text { - } & \text { Skill SDM } \\
\text { IKM } \\
\text { - Kemampuan } \\
\text { adopsi } \\
\text { inovasi }\end{array}$ & $\begin{array}{l}\text { Membentuk kelompok } \\
\text { pengrajin }\end{array}$ \\
\hline Machine & $\begin{array}{l}\text { - Kapasitas } \\
\text { Produksi alat } \\
\text { - Daya } \\
\text { adaptasi } \\
\text { SDM } \\
\text { terhadap alat }\end{array}$ & 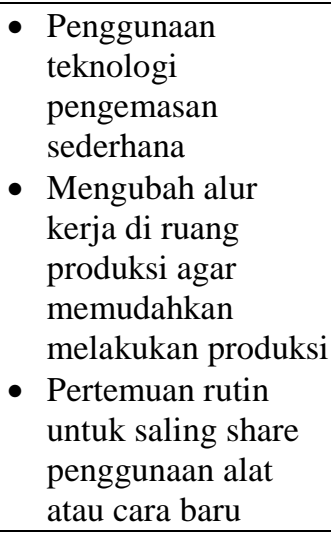 \\
\hline Money & $\begin{array}{l}\text { Keterbatasan } \\
\text { modal }\end{array}$ & - \\
\hline Material & $\begin{array}{l}\text { Kontinyuitas } \\
\text { bahan baku }\end{array}$ & $\begin{array}{l}\text { - Kerjasama dengan } \\
\text { petani ditingkat } \\
\text { hulu }\end{array}$ \\
\hline Methode & $\begin{array}{l}\text { - } \text { Cara } \\
\text { produksi } \\
\text { - Pengemasan }\end{array}$ & $\begin{array}{l}\text { - Sistem produksi } \\
\text { yang awalnya by } \\
\text { order kini mulai } \\
\text { melakukan stok } \\
\text { - Pengemasan sudah } \\
\text { mulai menarik, } \\
\text { menggunakan } \\
\text { mesin sealer dan } \\
\text { kemasan yang lebih } \\
\text { kedap udara }\end{array}$ \\
\hline
\end{tabular}




\section{KESIMPULAN}

Kesimpulan yang dapat ditarik adalah: (1) pendekatan human centered design dapat diterapkan secara luas untuk proses perancangan, inovasi, dan pemberdayaan masyarakat, baik di tingkat perkotaan maupun pedesaan; (2) dalam pengembangan industri kecil menengah, pendekatan human centered design dinilai cukup efektif, karena proses perbaikan sistem IKM berpusat pada pertimbangan kondisi manusia yang terkait dengan sistem IKM; (3) rangkaian setiap pra, proses, dan pasca Penerapan human centered design saling berkaitan dan menunjang keberhasilan dari tujuan yang akan dicapai; (4) hasil uji T menunjukkan adanya perbedaan yang signifikan tingkat produktifitas aktifitas bisnis IKM sebelum dan sesudah menerapkan konsep human centered design dalam aktifitas bisnisnya; dan (5) Industri kecil menengah berbasis olahan pangan di Pedesaan hendaknya memperhatikan : produk yang dikembangkan merupakan produk dengan bahan baku potensi setempat, diversifikasi produk dari yang sudah ada di daerah setempat, serta pemberdayaan komunitas desa.

Oleh karena itu, dibutuhkan kerjasama dengan pihak Pemerintah Daerah terkait pengembangan industry rumah tangga, peningkatan IPM dan kesejahteraan masyarakat untuk memudahkan proses pengembangan program secara berkelanjutan.

\section{DAFTAR PUSTAKA}

Kleiner, 1999. Macroergonomic Analysis and Design for improve safety and Quality Performance. International Journal of Occupational Safety and Ergonomic. Vol: 5, No.2, 217-245.

Rahmah \& Pujianto. 2014. Human centered design approach in agriculcural Small medium Enterprise Improvement Model. Prosiding 2ndICSAFS.

Stanton, et all. 2005. Handbook of Human Factors and Ergonomics Method. Washington DC : CRC Press. 